Transactions of the RHS 29 (2019), pp. I27-I5I (C) Royal Historical Society 2019. This is an Open Access article, distributed under the terms of the Creative Commons Attribution licence (http://creativecommons.org/licenses/by/4.o/), which permits unrestricted re-use, distribution, and reproduction in any medium, provided the original work is properly cited. doi:Io.IOI7/Soo80440IIgoooo69

\title{
PROPORTIONATE MAIMING: THE ORIGINS OF THOMAS JEFFERSON'S PROVISIONS FOR FACIAL DISFIGUREMENT IN BILL 64*
}

\author{
By Emily Cock \\ READ I4 APRIL 2018 \\ AT THE UNIVERSITY OF SOUTH WALES GARDIFF
}

\begin{abstract}
In I779, Thomas Jefferson proposed the use of nose-cutting to punish women convicted of specific offences, and the use of retaliation (lex talionis) for anyone who deliberately disfigured another person. These punishments were intended to replace the death penalty for these crimes, and as such formed part of Jefferson's attempt to rationalise the Virginian law code in line with eighteenth-century reform principles. Jefferson drew on British laws from the AngloSaxon period to the Coventry Act for his bill, but his proposals contrast strikingly with British movements away from corporal marking as punishment used against their own citizens. This article examines the origins and fates of equivalent crimes and punishments in the law codes Jefferson examined, and compares the legal and wider connotations of facial appearance and disfigurement that made these proposals coherent in Virginia when they had long ceased elsewhere. Tracing examples and discussion of these intersecting cases will greatly increase our understanding of Jefferson's proposals, and the relationships between facial difference, stigma and disability in eighteenth-century America.
\end{abstract}

CRYNODEB. Ym I779, cynigiodd Thomas Jefferson y dylid cosbi menywod a oedd yn euog o droseddau penodol drwy dorri eu trwynau, a defnyddio dial (lex talionis) ar gyfer unrhyw un a anffurfiodd berson arall yn fwriadol. Bwriad y cosbau hyn oedd disodli'r gosb eithaf ar gyfer y troseddau hyn, ac felly roeddent yn rhan o ymgais Jefferson i resymoli cod cyfreithiol Virginia yn unol ag egwyddorion diwygio'r ddeunawfed ganrif. Cynlluniodd Jefferson fesur ar sail cyfreithiau Prydeinig o'r cyfnod Eingl-Sacsonaidd hyd at Ddeddf Coventry, ond roedd ei gynigion yn cyferbynnu'n drawiadol â symudiadau Prydain oddi wrth gosbi ei dinasyddion yn gorfforol. Mae'r erthygl hon yn edrych ar darddiad a thynged troseddau a chosbau cyfatebol

*I would like to thank the audiences at Diverse Histories and the Cardiff Early Modern History seminar, and the reviewers at the Transactions, for their valuable feedback and suggestions on this article. I would also like to acknowledge a fellowship granted by the Robert H. Smith International Centre for Jefferson Studies at Monticello, and the warm support of their staff. 
y cyfreithiau roedd Jefferson yn eu harchwilio. Mae'n cymharu'r arwyddocâd cyfreithiol ac ehangach o ymddangosiad y wyneb ac anffurfio'r wyneb, a olygodd bod y cynigion hyn yn rhesymegol yn Virginia pan oeddent wedi dod $\mathrm{i}$ ben mewn mannau eraill ers amser maith. Byddwn yn cynyddu'n dealltwriaeth o gynigion Jefferson wrth olrhain enghreifftiau a thrafod yr achosion croestoriadol hyn, a'r berthynas rhwng anffurfio'r wyneb, stigma, ac anabledd yn America yn y ddeunawfed ganrif.

\section{Introduction}

Announcing that Thomas Jefferson (I743-I826) proposed boring a hole in the noses of women convicted of certain moral offences, and introducing an eye-for-an-eye system of retaliation (lex talionis) for anyone who disfigured any other person, tends to provoke a strong reaction. Even among those who see paradox in the author of the Declaration of Independence promoting equality of humanity while owning slaves, the punishments put forward by Jefferson in his proposed overhaul of capital offences in Virginian criminal law seem strange and anachronistic for a man thought preoccupied with eighteenth-century tastes for civility and legal reform.

Jefferson's proposals were the result of impressive research on common and statutory laws, preserved in his ample manuscript annotations in modern and Old English, Latin and French. They never became law: thus, while frequently acknowledged as anomalous to Jefferson's broader humanitarian principles, they have received less attention from Jefferson scholars. ${ }^{.}$Markus Dirk Dubber judged the bill a 'remarkable failure' in comparison to Jefferson's other reforms, symptomatic of the Early Republic's widespread inability to grapple with the philosophy and extent of legitimate punishment, and the relationships between legal persons and authority. ${ }^{2}$ Maurizio Valsania has recently offered fascinating close scrutiny of Jefferson's corporeality and attitudes towards others' bodies, but omits discussion about these proposals for punitive mutilation. 3 Yet Kathryn Preyer argued that the bill, along with Jefferson's proposals for religious freedom, property reform and free education, formed 'part of a single broad and energetic program of reform', and further scholars have traced the revolutionary effects of many of his proposals. ${ }^{4}$

\footnotetext{
${ }^{\text {I}}$ See e.g. Merrill D. Peterson, Thomas Jefferson and the New Nation: A Biography (New York, I970); John D. Bessler, Cruel \& Unusual: The American Death Penalty and the Founders' Eighth Amendment (Boston, MA, 2012), I43-5I.

${ }^{2}$ Markus D. Dubber, “An Extraordinarily Beautiful Document”: Jefferson's Bill for Proportioning Crimes and Punishments and the Challenge of Republican Punishment', in Modern Histories of Crime and Punishment, ed. Markus D. Dubber and Lindsay Farmer (Stanford, 2007), n.p. (Kindle edition).

${ }^{3}$ Maurizio Valsania, Fefferson's Body: A Corporeal Biography (Charlottesville, 2017).

${ }^{4}$ Kathryn Preyer, 'Two Enlightened Reformers of the Criminal Law: Thomas Jefferson in Virginia and Peter Leopold, Grand Duke of Tuscany', in Blackstone in America: Selected
} 
Jefferson also included the provisions in Notes on the State of Virginia (1787), thus giving them a much wider, international circulation. To understand Jefferson's proposals it is necessary to examine the fate of equivalent crimes and punishments in the law codes he examined, especially Britain's, and to compare the legal and wider connotations of facial disfigurement that made these proposals coherent in Virginia when they had long ceased elsewhere.

Prior to American independence, the common law of England was imported into the colonial courts, its decisions widely available in printed proceedings, and the Privy Council remained the highest appellate court. Jefferson's 'A Bill for Proportioning Crimes and Punishments in Cases Heretofore Capital' was Bill 64 of the ${ }_{2} 26$ bills prepared by himself, Edmund Pendleton and George Wythe for the revision of Virginia's laws. The criminal laws were initially assigned to George Mason, but Jefferson soon took over after Mason's retirement. 5 The committee submitted the bills to the legislature in 1779 . Bill 64 restricted execution to first degree murder and treason (more narrowly defined), and predominantly prescribed hard labour in the public works, and transplantation for slaves. The lack of a prison in the commonwealth precluded extensive incarceration.

The two provisions that deal with facial disfigurement, as written in Jefferson's fair manuscript copy, are as follows:

Whosoever shall be guilty of rape, polygamy, or sodomy with man or woman shall be punished, if a man, by castration, if a woman, by cutting thro' the cartilage of her nose a hole of one half inch diameter at the least.

and

Whosoever on purpose and of malice forethought shall maim another, or shall disfigure him, by cutting out or disabling the tongue, slitting or cutting off a nose, lip or ear, branding, or otherwise, shall be maimed or disfigured in like sort: or if that cannot be for want of the same part, then as nearly as may be in some other part of at least equal value and estimation in the opinion of a jury, and moreover shall forfeit one half of his lands and goods to the sufferer. ${ }^{6}$

Essays of Kathryn Preyer, ed. Mary Sarah Bilder, Maeva Marcus and R. Kent Newmyer (Cambridge and New York, 2009), 252-76, at 27I. Further Preyer, 'Crime, the Criminal Law and Reform in Post-Revolutionary Virginia', Law and History Review, I (I983), 53-85; Holly Brewer, 'Entailing Aristocracy in Colonial Virginia: "Ancient Feudal Restraints" and Revolutionary Reform', The William and Mary Quarterly 54 (1997), 307-46; Matthew Crow, Thomas Fefferson, Legal History, and the Art of Recollection (Cambridge, 2017).

${ }^{5}$ The original committee also included Thomas Lightfoot Lee, but he died soon after: Preyer, 'Crime', 56.

${ }^{6}$ '64. A Bill for Proportioning Crimes and Punishments in Cases Heretofore Capital, i8 June i779', Founders Online, National Archives (USA), last modified i3 June 2018, http:// founders.archives.gov/documents/Jefferson/OI-02-02-0132-0004-0o64 (original source: The Papers of Thomas Fefferson, vol. 2, I777-18 Fune I779, ed. Julian P. Boyd (Princeton, I950), 492-507); hereafter Bill 64 Online. 
The collection was put to the Assembly in the sessions of $1785^{-6}$, but only fifty-six bills were enacted into law. ${ }^{7}$ James Madison suggested to Jefferson (by then in Paris) that desire to retain horse stealing as a capital offence had contributed significantly to the defeat of the entire bill. ${ }^{8}$ The offences subsequently remained capital.

\section{Eighteenth-century law: death and violence}

The committee had agreed that the revisions to the criminal law should significantly reduce use of the death penalty, and Jefferson desired them 'strict and inflexible but proportioned to the crime'. ${ }^{9}$ He was influenced by writers like Cesare Beccaria, William Eden, Jean-Jacques Rousseau and Montesquieu, who emphasised proportionality of punishment and restriction of the death penalty as guarantors of individual rights and a check on state abuse. ${ }^{\text {Io }}$ The spectacle, ritual and vigour of corporal and capital punishments played a key role in performances of power by developing states in early modern Europe, and would arguably continue to do so in the fragile Early Republic. ${ }^{\text {II }}$ Judicial wounds to the face allowed for the ongoing stigmatisation of the individual alongside perpetual testimony to the power of authority.

The rise of a progressive penology from the late eighteenth century, emphasising reform rather than retribution, and especially the turn toward imprisonment, would significantly decrease or remove corporal and capital punishments from most European and American jurisdictions. Scholars have highlighted a decreasing acceptance of violence in Britain over the course of the eighteenth century, which accompanied the decline in public corporal punishments and eventually the death penalty. ${ }^{12}$ As Randall McGowen notes, scholarship on early modern punishments has nevertheless substantially complicated understanding of the move from bodily punishments to the mind (as Michel Foucault

\footnotetext{
${ }^{7}$ Jefferson, Autobiography, in The Works of Thomas Fefferson, Federal Edition, ed. Paul Leicester Ford (I2 vols., New York, I904), II, 385 .

${ }^{8}$ James Madison to Jefferson, I5 February I787. All letters are taken from the National Archives (USA), Founders Online, https://founders.archives.gov/.

${ }^{9}$ Jefferson to Pendleton, 26 August 1776.

${ }^{\text {IO }}$ Frank McLynn, Crime and Punishment in Eighteenth-Century England, I989 (Oxford, I99I), 253; Leon Radzinowicz, A History of English Criminal Law and Its Administration from $1750(5$ vols., I948), I, 369-70.

${ }^{\text {II } D a v i d ~ G a r l a n d, ~ ' M o d e s ~ o f ~ C a p i t a l ~ P u n i s h m e n t: ~ T h e ~ D e a t h ~ P e n a l t y ~ i n ~ H i s t o r i c a l ~}$ Perspective', in America's Death Penalty: Between Past and Present, ed. David Garland, Randall McGowen and Michael Meranze (New York, 201 I), 30-7I.

${ }^{12}$ Peter King, 'Punishing Assault: The Transformation of Attitudes in the English Courts', Fournal of Interdisciplinary History, 27 (1996), 43-74; Robert Shoemaker, 'Male Honour and the Decline of Public Violence in Eighteenth-Century London', Social History, 26 (200I), I90-208.
} 
famously framed it), highlighting the role of shame, pain, sympathy and salvation within the symbolic universe in which these punishments operated. ${ }^{13}$ Medievalists have also highlighted the legitimation required for the infliction of disfiguring violence by rulers in that period. ${ }^{14}$ Violence did not disappear from the British Atlantic: one facet of the tense distinction between not only Britons and colonised peoples, but Britons living in Britain against those in the colonies, was acceptance of violence in peripheral zones, combined with emphasis on legal and customary niceties, which concealed contests of authority and justice. ${ }^{5}$ Scholars of colonialism have complicated the modernising narrative of crime and punishment by highlighting ways in which penal practices followed different paths in colonies and regions within them, the fact that these subsequently affected the metropoles, and that violence toward subjugated groups and individuals was integral to Enlightenment philosophies. ${ }^{\mathrm{I}} 6$ Within a colony, infliction of 'English' punishments, even on settlers, was a means of reiterating authorities' and the community's adherence to ideals of civilisation. ${ }^{\mathrm{I}}$ The American South remained rooted in codes of honour, including expectations of violence to defend it whether eye-gouging, the duel or nose-pulling - and militarily active. ${ }^{\text {I8 }}$

\footnotetext{
${ }^{13}$ Randall McGowen, 'Through the Wrong End of the Telescope: History, the Death Penalty and the American Experience', in America's Death Penalty, ed. Garland, McGowen and Meranze, Io6-28, at III-I2; Garland, 'Modes of Capital Punishment', 49; Michel Foucault, Discipline and Punish: The Birth of the Prison, 1975, trans. Alan Sheridan (1977); Robert Shoemaker, 'Streets of Shame? The Crowd and Public Punishments in London, I700-1820', in Penal Practice and Culture, I500-1900, ed. Simon Devereuaux and Paul Griffiths (Houndmills, 2004), 232-57; Pieter Spierenberg, The Spectacle of Suffering: Executions and the Evolution of Repression: From a Preindustrial Metropolis to the European Experience (Cambridge, I984).

${ }^{14}$ Patricia Skinner, 'Visible Prowess?: Reading Men's Head and Face Wounds in Early Medieval Europe to Iooo CE', in Wounds and Wound Repair in Medieval Culture, ed. Larissa Tracy and Kelly DeVries (Leiden, 20I5), 8I-IoI.

${ }^{15}$ Eliga H. Gould, 'Zones of Law, Zones of Violence: The Legal Geography of the British Atlantic, circa 1772', The William and Mary Quarterly, 6o (2003), 47-5-510, at 473, 500; and Among the Powers of the Earth: The American Revolution and the Making of a New World Empire (Cambridge, MA, 2012), 59-63.

${ }^{16}$ Kerry Ward, 'Defining and Defiling the Criminal Body at the Cape of Good Hope: Punishing the Crime of Suicide under Dutch East India Company Rule, circa 1652I795', in Discipline and the Other Body: Correction, Corporeality, Colonialism, ed. Steven Pierce and Anupama Rao (Durham, NC, 2006), 35-6o, at 38; Lauren Benton, Law and Colonial Cultures: Legal Regimes in World History, I400-1900 (Cambridge, 2002).

${ }^{17}$ Michael Meranze, Laboratories of Virtue: Punishment, Revolution, and Authority in Philadelphia, I760-I835 (Chapel Hill, I996), I88.

${ }^{18}$ Edward L. Ayers, Vengeance and Fustice: Crime and Punishment in the Igth-Century American South (New York, I984), 2I; Kenneth S. Greenberg, 'The Nose, the Lie, and the Duel in the Antebellum South', American Historical Review, 95 (1990), 57-74; Elliott J. Gorn, "Gouge and Bite, Pull Hair and Scratch": The Social Significance of Fighting in the Southern Backcountry', American Historical Review, 90 (1985), I8-43.
} 
Studies of Jefferson's attitude toward physical punishments have focused on his reticence to use physical violence on his own slaves: he has been considered a 'better' sort of slave-owner in this respect, preferring to sell off troublemakers. ${ }^{19}$ However, Jefferson's relation to violence has come under revision in light of insights into the manner in which violence was entrenched and strategically manoeuvred in the period. There is also vital and growing scholarship on the disabling of enslaved communities. ${ }^{20}$ As Tristan Stubbs notes, Enlightenment patriarchs like Jefferson in many cases displaced blame for violence onto figures such as overseers, while their own force was 'subsumed into gentler rhetoric'. ${ }^{21}$ Jefferson's strategic use of supervision at Monticello also introduced what scholars have recognised as principles of the panopticon to his plantation. ${ }^{22}$

Jefferson argued that writers like Beccaria 'had satisfied the reasonable world of the unrighteousness and inefficacy of the punishment of crimes by death'. ${ }^{23}$ Jefferson's legal commonplace book demonstrates his extensive engagement with Beccaria's views. ${ }^{24}$ He stopped short of following Beccaria's call for abolition of the death penalty, nor does Stuart Banner find much evidence for disapproval of the punishment across colonial America. ${ }^{25}$ Beccaria also objected to differentiation of punishments for repeat offenders, which was a major source of mutilation punishments in the American context, including the benefit of clergy that Jefferson removed. ${ }^{26}$ Text added to the final bill suggests he was not alone in the opinion that 'a hope of impunity' encouraged offenders, and therefore the best thing for a strong law was the image of fair inflexibility. ${ }^{27}$ Jefferson argued that restriction of the death penalty would be more humane, but also that 'cruel and sanguinary laws' accompanied by too much judicial discretion discouraged prosecutions, and induced

\footnotetext{
${ }^{19}$ Joseph J. Ellis, American Sphinx: The Character of Thomas Fefferson (New York, I997), I49; Valsania, Jefferson's Body, i27.

${ }^{20}$ E.g. Dea H. Boster, African American Slavery and Disability: Bodies, Property, and Power in the Antebellum South, I800-I860 (2013).

${ }^{21}$ Tristan Stubbs, Masters of Violence: The Plantation Overseers of Eighteenth-Century Virginia, South Carolina, and Georgia (Columbia, 2018), 4.

${ }^{22}$ Valsania, Fefferson's Body, i23-8; Terrence W. Epperson, 'Panoptic Plantations: The Garden Sights of Thomas Jefferson and George Mason', in Lines That Divide: Historical Archaeologies of Race, Class, and Gender, ed. James A. Delle, Stephen A. Mrozowski and Robert Paynter (Knoxville, 2000), 58-77.

${ }^{23}$ Jefferson, in Works of Thomas Fefferson, ed. Ford, I, 7I.

${ }^{24}$ Jefferson, Jefferson's Legal Commonplace Book, ed. David Thomas Konig and Michael

P. Zuckert (Princeton, 20I9), 49I-524. Further Preyer, 'Cesare Beccaria and the Founding Fathers', in Blackstone in America, ed. Bilder, Marcus and Kent, ch. 8.

${ }^{25}$ Stuart Banner, The Death Penalty: An American History (Cambridge, MA, 2002), 23.

${ }^{26}$ Cesare Beccaria, On Crimes and Punishments, ed. Richard Bellamy, trans. Richard Davies (Cambridge, 1995), ch. 4 .

${ }^{27}$ The Bill as presented to the Assembly: Works of Thomas Fefferson, ed. Ford, II, 395.
} 
local judges to listen to evidence with 'bias', and 'smother testimony' ${ }^{28}$ The same publicness and deep ingratiation within local communities that made the application of the law, and especially shaming punishments such as the pillory, so effective, also threatened its impartial application.

Jefferson demonstrates a volte-face around the efficacy of shaming for criminal reform. Even when sending a draft of Bill 64 to Wythe, he expressed concern that the punishments would 'exhibit spectacles in execution whose moral effect would be questionable'. ${ }^{29}$ Nevertheless, the opening of the bill referred hopefully to the 'reformed' individuals serving as 'living and long continued spectacles to deter others from committing the like offences'. $3^{\circ} \mathrm{He}$ also retained shaming punishments like the pillory, and ducking for pretensions to witchcraft. Nevertheless, in his autobiography Jefferson expressed dissatisfaction with the way humiliating public labour in Pennsylvania 'with shaved heads and mean clothing ... produced in the criminals such a prostration of character, such an abandonment of self-respect, as, instead of reforming, plunged them into the most desperate and hardened depravity of morals and character'. ${ }^{3}$ His inclination was thereafter toward imprisonment, in which he coincided with the general shift across the country. ${ }^{2}$

\section{Jefferson's sources}

Jefferson covered Bill 64 in neat annotations. The key legal authorities he cites are Fleta, Bracton and Britton. 'Fleta' ( $f$. I290-1300) is the name used for the author of a Latin treatise on English law (Fleta) that updated and reorganised Henry of Bratton's (d. I268) slightly earlier De legibus et consentudinibus Angliae. The text only survives in one manuscript, but the later Anglo-Norman Britton, based on Fleta, enjoyed much greater circulation in the fourteenth century. Fleta was then revitalised as a legal authority in the early seventeenth century by Sir Edward Coke. ${ }^{33}$ Jefferson owned the first printed edition of Fleta in Latin (I647), a I640 edition of Britton (also Latin) and Edmund Wingate's I640 English translation of Bracton. He also draws on his copies of Coke's Institutes

\footnotetext{
${ }^{28}$ Bill 64 Online.

${ }^{29}$ Jefferson to Whythe, I November 1778.

${ }^{30}$ Bill 64 Online. See also Jefferson to Pendleton, 26 August I776. Jefferson expands on public labour in Bill 68.

${ }^{31}$ Jefferson, in Works of Thomas Fefferson, ed. Ford, I, 72.

${ }^{32}$ Adam Jay Hirsch, The Rise of the Penitentiary: Prisons and Punishment in Early America (New Haven, I992); Meranze, Laboratories of Virtue.

${ }^{33}$ David J. Seipp, 'Fleta (fl. I290-I30o)', Oxford Dictionary of National Biography, Oxford University Press, 2004, www.oxforddnb.com/view/article/9716 (accessed II November 2016).
} 
of the Lawes of England (1628), the I759 translation of Sir Henry Finch's legal digest (Law, or, a Discourse thereof) and Sir William Blackstone's Commentaries on the Lawes of England (1765-9).34 Coke and Blackstone were the most widely read legal authorities in Virginia, making them sensible sources to highlight, although Jefferson always preferred what he considered Coke's Whig mentality over Blackstone's Toryism. 35

Jefferson framed his use of medieval law codes very carefully. He professed his role in the criminal law revisions as being in general ... to reduce the law to its antient Saxon condition, stripping it of all the innovations \& rigorisms of subsequent times, to make it what it should be'. ${ }^{6}$ The revision of the laws played an important part in the negotiation of independent American identity. Europe and especially Britain continued to be the benchmark against which American elites measured civility and rule of law, and this inferiority anxiety was a major driver of legal reforms. 37 While all states addressed the status of laws inherited from England, some were content to distinguish American legal identity by retaining common law unless 'repugnant' to the constitution. ${ }^{8}$ One of the ways in which Jefferson negotiated a break between 'English' and 'American' was to return to the world of the pre-Norman-conquest Anglo-Saxon, positioning America as the inheritor of this tradition, and encouraging study of the laws, language and culture. He considered his own Whig politics, grounded in the rights of Parliament and the people, to be based ultimately in Anglo-Saxon codes, while the Tory focus on hereditary rule and arbitrary authority found its roots in the Norman influence. 39

This positioning also accounts for notable omissions from Virginian law. The most significant are The Lawes Divine, Morall and Martiall (Dale's laws), active in Virginia from I6II-I8 but shaping Virginia's

\footnotetext{
${ }^{34}$ Confirmed through Thomas Jefferson's library catalogues: http://tjlibraries.monticello. org/search/search.html (accessed 2 September 2018).

${ }^{35}$ W. Hamilton Bryson, 'Legal Education', in Virginia Law Books: Essays and Bibliographies, ed. W. Hamilton Bryson (Philadelphia, 2000), 316-96, at 322, 332; Dubber, "'An Extraordinarily Beautiful Document".

${ }^{36}$ Jefferson to Skelton Jones, 28 July I8og.

${ }^{37}$ Kariann Akemi Yokota, Unbecoming British: How Revolutionary America Became a Postcolonial Nation, 20II (New York, 20I4); Ellen Holmes Pearson, 'Revising Custom, Embracing Choice: Early American Legal Scholars and the Republicanization of the Common Law', in Empire and Nation: The American Revolution in the Atlantic World, ed. Eliga H. Gould and Peter Onuf (Baltimore, 2005), 93-III.

${ }^{3}$ Mary Sarah Bilder, The Transatlantic Constitution: Colonial Legal Culture and the Empire (Cambridge, MA, 2004), I87.

${ }^{39}$ John D. Niles, The Idea of Anglo-Saxon England Io66-I9or: Remembering, Forgetting, Deciphering and Renewing the Past (Chichester, 2015), 268; María José Mora and María José Gómez-Calderón, 'The Study of Old English in America (I776-I850): National Uses of the Saxon Past', Journal of English and Germanic Philology, 97 (1998), 322-36.
} 
authoritarian legal style through the seventeenth century. $4^{\circ}$ The Lawes followed contemporary models from the Star Chamber in prescribing ear-cutting for accessories to the destruction of livestock (article 2I), or perpetrators of a range of food adulterations and thefts (article 37), among other mutilations (there were no provisions for boring the nose). ${ }^{4 \mathrm{I}}$ They had been published in London to reassure English investors that Virginia was being run strictly and efficiently, and in close alignment with English law, thus representing a deviation from Jefferson's desired Anglo-Saxon models. ${ }^{2}$

\section{The face in Virginia}

Jefferson's provisions to both prevent and enforce forms of disfigurement attest to the importance of appearance. There has been increasing attention paid to Jefferson's own face and body - health, decorum, dress and the construction of what biographers following Merrill D. Peterson have assessed as his 'impenetrable' image. 43 The circulation of political portraiture, including Jefferson's, was a valuable tool for the embodiment of 'abstract ideals of civic virtue' in post-revolutionary America. ${ }^{44}$ At the same time, portraits were afflicted with the classic conundrum of balancing esteemed qualities of beauty and dignity, including influence from physiognomy, with the need to present a recognisable likeness.

There was significant interest in appearance and identity among highly mobile populations disturbed by war, with frequent emigration to and between colonies, including receipt of banished legal, religious, political or criminal dissidents, where traditional markers like dress and speech did not necessarily correlate with social rank, national identity or free status. 45 Visiting America in I833, Alexis de Tocqueville

$4^{\circ}$ Meranze, Laboratories of Virtue, Igo.

${ }^{4 \mathrm{I}}$ For the Colony in Virginea Britannia. Lawes Divine, Morall and Martiall, E'c. (London: Walter Burre, I6I2), sigs. $\mathrm{C}_{2}{ }^{\mathrm{v}}, \mathrm{D}_{\mathrm{I}}^{\mathrm{v}}-\mathrm{D}_{2}{ }^{\mathrm{r}}$; David Thomas Konig, "Dale's Laws" and the NonCommon Law Origins of Criminal Justice in Virginia', American Fournal of Legal History, 26 (I982), 354-75, at 370 .

$4^{2}$ David H. Flaherty (introduction and ed.), For the Colony in Virginea Britannia, Lawes Divine, Morall and Martiall, etc. Compiled by William Strachey (Charlottesville, I969), xx.

${ }^{43}$ Peterson, Thomas Jefferson, viii, cited in Peter S. Onuf, The Mind of Thomas Jefferson (Charlottesville, 2007), 3; Valsania, Jefferson's Body; David Waldstreicher, 'Why Thomas Jefferson and African Americans Wore Their Politics on Their Sleeves: Dress and Mobilization between American Revolutions', in Beyond the Founders: New Approaches to the Political History of the Early American Republic, ed. Jeffrey L. Pasley, Andrew W. Robertson and David Waldstreicher (Chapel Hill, 2004), 79-ı03; G. S. Wilson, Fefferson on Display: Attire, Etiquette, and the Art of Presentation (Charlottesville, 2018).

${ }^{44}$ Christopher J. Lukasik, Discerning Characters: The Culture of Appearance in Early America (Philadelphia, 20II), I22.

${ }^{45}$ E.g. Gwenda Morgan and Peter Rushton, Banishment in the Early Atlantic World: Convicts, Rebels and Slaves (20I3); Lukasik, Discerning Characters, ch. 2 and passim. 
commented on the ease with which offenders could move from state to state, avoiding recognition for their crimes in new communities. ${ }^{4}$ Identity papers, passes for servants and slaves, hygiene practices, racial science, tattoos and other features were harnessed for the sake of constructing, defining and reading difference between bodies. 47 From the selective outward identification of specific deviant groups and individuals, the development of the passport from the late eighteenth century marked a new interest in a system of identification and surveillance applicable to all citizens. ${ }^{8}$ The physiognomical theories of Johann Casper Lavater contributed to scrutiny of character in the face, and Jefferson was himself intrigued by racialised differences (and hierarchies) between bodies, including facial distinctions. 49

\section{Bill 64: reducing capital offences}

This was the context in which Jefferson presented Bill 64. The initial committee plan of January I777 did not include specific punishments for disfiguring or maiming, and only stipulated castration for rape, sodomy and bestiality. ${ }^{\circ}$ On I November 1778 Jefferson sent the bill to Wythe, asking him to 'scrupulously ... examine and correct it', including his notes on the law's sources. In this letter he suggests that he has 'strictly observed the scale of punishments settled by the Committee, without being entirely satisfied with it':

The lex talionis, altho' a restitution of the Common law, to the simplicity of which we have generally found it so advantageous to return will be revolting to the humanised feelings of modern times. An eye for an eye, and a hand for a hand will exhibit spectacles in execution whose moral effect would be questionable; and even the membrum pro membro of Bracton or the punishment of the offending member, altho' long authorised by our law, for the same offence in a slave, has you know been not long since repealed in conformity with public sentiment. This needs reconsideration. ${ }^{5}$

\footnotetext{
${ }^{46}$ Simon A. Cole, Suspect Identities: A History of Fingerprinting and Criminal Identification (Cambridge, MA, 200I), I7.

${ }^{47}$ Kathleen M. Brown, Foul Bodies: Cleanliness in Early America (New Haven, 2009); Nathan Perl-Rosenthal, Citizen Sailors: Becoming American in the Age of Revolution (Cambridge, MA, 2015); Craig Robertson, The Passport in America: The History of a Document (Oxford, 2010).

${ }^{48} \mathrm{Jane}$ Caplan and John Torpey, 'Introduction', in Documenting Individual Identity: The Development of State Practices in the Modern World, ed. Jane Caplan and John Torpey (Princeton, 200I), I-I2, at 8.

${ }^{49}$ Lukasik, Discerning Characters, II; Charles A. Miller, Jefferson and Nature: An Interpretation (Baltimore, 1988), ch. 3; Jay Fliegelman, Declaring Independence: Fefferson, Natural Language \& the Culture of Performance (Stanford, I993), I92-5.

$5^{\circ}$ 'I. Plan Agreed upon by the Committee of Revisors at Fredericksburg, [I3 January I777]', Founders Online, National Archives, last modified i3 June 2018, http://founders. archives.gov/documents/Jefferson/OI-O2-O2-OI32-0002 (original source: The Papers of Thomas Fefferson, vol. 2, ed. Boyd, 325-8).

${ }^{51}$ Jefferson to Wythe, I November 1778 .
} 
Jefferson expressed similar sentiments in his later autobiography, professing 'How ... [the lex talionis] came to obtain our approbation I do not remember. ${ }^{2}$ It is also absent from the only surviving record of the committee's meeting - Mason's notes - suggesting that its inclusion was actually all Jefferson. 53 Examining Jefferson's research through his notes, and the legal attitudes toward disfigurement in relevant jurisdictions can help to shed light on this decision.

\section{Bestiality}

Jefferson reasoned that bestiality was not 'injurious to society in any great degree' and was therefore outside the rights of criminal law. He also remarked that it 'will ever be properly and severely punished by universal derision', thus revealing his reliance on community shaming efforts.54 There were very infrequent cases in the Commonwealth, which scholars have interpreted as reluctance among communities to prosecute the action as capital, rather than an accurate indication of the number of occurrences. ${ }^{55}$ While we await a full analysis of Jefferson and animal rights, his quasi-vegetarianism and idealism in regard to agriculture and the civilising potential of animal husbandry (especially for Native Americans) are well-established parts of his character..$^{6}$

\section{Suicide}

Probably influenced by Beccaria, Jefferson quietly rescinded the forfeiture of property by anyone who committed suicide, considering it not only a useless deterrent to one really 'so weary of his existence here' but one that in practice had only led to fictitious judgements of insanity in order to preserve the inheritance of bereaved families.57 Terri L. Snyder highlights Jefferson's accordance with wider secularisation in the understanding of suicide, and that local authorities and juries had been reluctant to take action against suicides when it meant forgoing

\footnotetext{
${ }^{52}$ Jefferson, in Works of Thomas Fefferson, ed. Ford, I, 69.

${ }^{53}$ Dubber, "“An Extraordinarily Beautiful Document".

${ }^{54}$ Bill 64 Online.

${ }^{55}$ John M. Murrin, "'Things Fearful to Name"': Bestiality in Colonial America', Pennsylvania History: A Fournal of Mid-Atlantic Studies, 65 (1998), 8-43, at I2; Colleen Glenney Boggs, Animalia Americana: Animal Representations and Biopolitical Subjectivity (New York, 2013), 50-I.

${ }^{5}{ }^{6}$ Valsania, Fefferson's Body, 75; Virginia DeJohn Anderson, Creatures of Empire: How Domestic Animals Transformed Early America (Oxford, 2004), 245; M. L. Wilson, 'Thomas Jefferson - Farmer', Proceedings of the American Philosophical Society, 87 (1943), 216-22.

${ }^{57}$ Jefferson, in Works of Thomas Fefferson, ed. Ford, II, 40I, including Beccaria.
} 
the deceased's property to the Crown and forcing local authorities to support their family..$^{8}$

\section{Polygamy}

Jefferson added polygamy himself, acknowledging that according to Blackstone it had only been a capital offence in England since I6o4, where instead the law was satisfied with its 'nullity'.59 Polygamy was omitted from the final bill: it therefore remained capital in Virginia until I8I9, when it was replaced with up to ten years' incarceration, representing what John Witte judges the 'typical' easing of its punishment across the country. ${ }^{60}$ Jefferson might have been influenced as much by Pennsylvania's non-capital punishment as by general liberalism, but his ultimate reluctance to remove the crime speaks to the seriousness with which he judged the offence.

\section{Rape}

Jefferson had admitted to Madison in December i786 that, in contrast to the success of his religious freedom bill, his lex talionis measures failed to find much approval in Europe. Utilising 'retaliation' for rape was judged 'indecent and unjustifiable'. He appears to be speaking only of male castration since he goes on to express concern that women will use a false rape charge as an 'instrument of vengeance against an inconstant lover' ${ }^{6 r}$ The Virginian legislature had severely restricted punitive castration, and in the nineteenth century it was limited to enslaved men convicted of raping a white woman; other jurisdictions like New Jersey and Pennsylvania extended this punishment to Native American and white men, respectively, even if there is no evidence for the latter that the sentence was ever carried out. ${ }^{62}$

\section{Sodomy}

Virginia, leading the five southern colonies, had adopted the Tudor definition and capital punishment for sodomy without enacting its own

\footnotetext{
${ }^{58}$ Terri L. Snyder, 'What Historians Talk about When They Talk about Suicide: The View from Early Modern British North America', History Compass, 5 (2007), 658-74, at $66_{3}, 668$.

${ }^{59}$ Bill 64 Online; William Blackstone, Commentaries on the Laws of England (4 vols., Oxford, I765-9), IV, I64.

${ }^{60} \mathrm{John}$ Witte, The Western Case of Monogamy over Polygamy (New York, 2015), 400.

${ }^{6} \mathrm{~J}$ Jefferson to Madison, i6 December 1786.

${ }^{62}$ Diane Miller Sommerville, Rape and Race in the Nineteenth-Century South (Chapel Hill, 2004), 74-5.
} 
statutes on the matter. ${ }^{6} 3$ Subsequent English cases had established high levels of proof of penetration, the irrelevance of consent, etc., and it remained a rare prosecution; John M. Murrin cites only one confirmed sodomy trial in colonial Virginia. ${ }^{6}$ It seems unlikely that women would actually be considered legally capable of sodomy in practice (or similarly, rape), but Jefferson does include this possibility both through the specific punishment, and through including a supporting gloss from Finch that sodomy denoted 'carnal copulation against nature, to wit, of man or woman in the same sex'. ${ }^{6}$

\section{Disfigurement as a crime}

My search of the limited evidence we have for court decisions in Virginia has failed to unearth any cases offering significant revision of, or prosecution under, laws against inflicting disfiguring injuries. ${ }^{66}$ Prior to the Revolution, English statutory and common law was therefore the most relevant corpus available. The first reference for any lawyer of the period was of course Blackstone's Commentaries. Blackstone discusses common law mayhem's stress on utility, specifically for battle: thus, 'cutting off [a man's] ear, or nose, or the like, are not held to be mayhems at common law; because they do not weaken but only disfigure him'. Nevertheless, 'striking out his eye or foretooth' was classically mayhem, showing the aesthetic component that carried into the common law. ${ }^{67}$ In his notes, Jefferson quotes further from Britton and Fleta on the definition of mayhem as injury affecting capacity for battle. ${ }^{68}$ Meanwhile, early modern statutes offered limited protection from crimes against the person not resulting in death. ${ }^{69}$ Maliciously

\footnotetext{
${ }^{63}$ Louis Crompton, 'Homosexuals and the Death Penalty in Colonial America', Fournal of Homosexuality, I (I976), 277-93, at 278. Jefferson cites 25 Henry 8. c. 6.

${ }^{64}$ Murrin, "Things Fearful to Name", , 2.

${ }^{65}$ Finch in Jefferson, Bill 64 Online; Henry Finch, Law, or, a discourse thereof(London, I759), 219 .

${ }^{66}$ Jefferson, Reports of Cases Determined in the General Court of Virginia. From I730, to I740; and From I768, to I772 (Charlottesville, I829); Virginia Colonial Decisions: the reports by Sir Fohn Randolph and by Edward Barradall of decisions of the general court of Virginia, I728-I74I, ed. R. T. Barton (Boston, MA, Igog); William W. Hening and William Munford, Reports of Cases Argued and Determined in the Supreme Court of Appeals of Virginia (4 vols., Philadelphia, I8oI-II); Bushrod Washington, Reports of Cases Argued and Determined in the Court of Appeals of Virginia (2 vols., Richmond, I798-9).

${ }^{67}$ Blackstone, Commentaries, IV, 205-6; Patricia Skinner, Living with Disfigurement in Early Medieval Europe (New York, 20I7), 69.

${ }^{68}$ Edmund Wingate (ed.), Britton, The Second Edition (London: John Moore, I640), sigs. F8v-Giv'; 'Fleta' and John Selden, Fleta seu Commentarius Furis Anglicani sic nuncupatus (London: William Lee and Daniel Pakeman, I647), sigs. II ${ }^{\mathrm{v}}-\mathrm{I}_{2}{ }^{\mathrm{r}}$.

${ }^{69}$ William Holdsworth, A History of English Law, 5th edn (I2 vols., I942), VI, 403 .
} 
cutting out the tongue or eyes was felony under 5 Hen. 4 . c. $5 .^{70}$ This was followed by 37 Hen. 8 c. 6 , which targeted malicious cutting of the ears, with a necessary exemption for ears cut 'by authority of law'. ' $^{\mathrm{I}}$

The most important statutory intervention occurred in 1670 , and became known as the Coventry Act. This formed the basis of all subsequent colonial disfigurement statutes, including Jefferson's revision. The Act rendered it an unclergyable felony to

on purpose and of malice forethought and by lyeing in waite ... unlawfully cutt out, or disable the Tongue, putt one out an Eye, slitt the Nose, cutt off a Nose or Lipp, or cutt off, or disable any Limbe or Member of any Subjectt of his Majestie with intention in soe doeing to maime or disfigure in any the manners before mentioned such his Majestyes Subject [or to be one of] their Councellours Ayders and Abetters (knowing of and privy to the Offence as aforesaid)[.] $]^{72}$

Sir John Coventry had provoked James Scott, ist Duke of Monmouth, by remarking on Charles II's fondness for actresses in a parliamentary debate. Subsequently, over twenty-five of the duke's men lay in wait and cut Coventry's nose almost clean from his face. Injuries to the nose carried specific symbolic weight, but debates show that Parliament's swift statutory response was as driven by the fact it was an attack on a sitting member as by horror at discovering the wound's legal weakness. 73 The Lords were the most adamant that intention must be explicitly required for felony without benefit of clergy, and that a provision for lying in wait should prevent any 'genuine' fights that happened to result in otherwise actionable injuries from coming under the statute.74 These requisites would significantly restrict the Act's application. Where they were not met, the defendant was liable for only a fine and imprisonment. The limitations of the Act prompted further legislation to protect officials: 9 Anne c. I6 made it an unclergyable felony to attempt to kill, or strike, assault or wound a privy counsellor in the execution of his office. Like Coventry, this Act was a direct response to a contemporary event, after the Marquis de Guiscard

${ }^{70}$ Sir John Gonson, Sir Fohn Gonson's Three Charges to Several Grand Juries, 2nd edn (1728), 70.

${ }^{71}$ Joseph Chitty, A Practical Treatise on the Criminal Law, $4^{\text {th }}$ edn (3 vols., Springfield, I84I), III, 784; Frank Aydelotte, Elizabethan Rogues and Vagabonds, I9I3 (Abingdon, I967), 58.

${ }^{72}$ 'Charles II, I670 \& I671: An Act to p[re]vent Malitious maiming and wounding', in Statutes of the Realm: Volume 5, I628-80, ed. John Raithby (s.1. 1819), 69I-2. British History Online, www.british-history.ac.uk/statutes-realm/vol5/pp69I-692 (accessed i3 September 2018).

${ }^{73}$ 'Debates in I67I: January (Ist-I7th)', in Grey's Debates of the House of Commons: Volume I, ed. Anchitell Grey (I769), 333-53. British History Online, www.british-history.ac.uk/greysdebates/voli/pp333-353 (accessed i3 September 2018).

74 'House of Lords Journal Volume I2: 28 January I67I', in Fournal of the House of Lords: Volume I2, I666-I675 (1767-1830), 415-16. British History Online, www.british-history.ac.uk/ lords-jrnl/volı2/pp4I5-4I6 (accessed i3 September 20I8). 
stabbed the Chancellor of the Exchequer, Robert Harley, in the chest with a penknife in March I7I I. ${ }^{75}$

The Virginia General Assembly issued an Act closely following Coventry in I752. It allowed benefit of clergy, but did not require 'malice' or 'lying in wait'. $7^{6}$ Another 1772 Act focused on 'gouging, plucking or putting out an eye, biting, kicking, or stamping upon' an individual, which if 'wilful or malicious' should be met with a suit for damages, and the offender whipped if he failed to pay. A suit could also be brought by a third party if the victim failed to act, with damages split between the prosecutor and churchwardens for the support of parish poor.77 The Privy Council overruled the law for applying a criminal penalty to a civil suit. $7^{8}$ Elliot J. Gorn noted that the shift of emphasis in this statute reflected concern about the rough fighting popular in the Virginia backcountry, where eye-gouging was a winning blow, but without acknowledging the extent to which statutes enacted in different colonies merely built upon the Coventry Act.79

In the absence of Virginian cases, English trials against the Coventry Act can shed significant light on the reception of disfigurement in the period, and legal attitudes to its restitution. In general, the reticence which met application of the Act and its capital punishment are commensurate with Jefferson's rescinding of the death penalty. They also illuminate the vagaries of the Act's application that led to dissatisfaction in the legal profession. Jefferson had informed Pendleton in his plans for the bill of his desire to 'let the judge be a mere machine'. ${ }^{80}$ Coventry Act cases had seen them anything but.

Few cases were easily resolved. The very first was a notable exception, in which siblings William, Robert and Mary Dine were indicted for attacking Jane King in I677. It was a sensational trial, widely reported, and they were executed. But most prosecutions, even if successful, produced worrying questions of law. In the case cited by Blackstone, and widely elsewhere, a lawyer, Arundel Coke (aka Cooke), was found guilty of slitting the nose of his brother-in-law Edward Crispe, with the assistance of John Woodburne, in Suffolk, I72I. ${ }^{81}$ The trial became infamous for Coke's attempted defence that he had intended to murder Crispe, and therefore did not meet the statute's criteria, and the Lord

${ }^{75}$ Blackstone, Commentaries, I, 225.

${ }^{76}$ William Waller Hening, The Statutes at Large; Being a Collection of all the Laws of Virginia, from the First Session of the Legislature, in the Year I6Ig (I3 vols., Philadelphia, I809-23), VI, 250.

${ }^{77}$ Ibid., VIII, 520-2.

${ }^{78}$ Preyer, 'Crime', 67.

${ }^{79}$ Gorn, "Gouge and Bite", I9.

${ }^{80}$ Jefferson to Pendleton, 26 August 1776.

${ }^{8 \mathrm{I}}$ Blackstone, Commentaries, IV, 207; The Tryal and Condemnation of Arundel Coke alias Cooke Esq; and of John Woodburne Labourer, for Felony, in Slitting the Nose of Edward Crispe Gent. (I722). 
Chief Justice Sir Peter King's rather convoluted ruling on the nature of intent in felony cases to ensure that they did not escape on such a defence. Southwell JP Ralph Heathcote attacked the ruling in a legal treatise that Jefferson owned, stating 'that no true man of the Profession was ever heard to speak with temper upon the Case'. Believing that they did indeed intend to kill rather than disfigure Crispe, Heathcote argued that the Act was wrongfully construed, 'and the same constructive violence, in the interpretation of Laws, might often hang an honest man as well as a knave'.$^{82}$ A related standard in English and therefore prior Virginian law made it murder to accidentally kill someone in commission of an unlawful act, regardless of intention; Jefferson's bill explicitly rescinded this equivalence, formalising the need to prove intention for either manslaughter or murder.

In another widely cited case, William Lee was indicted under the Act in 1763 for cutting his sleeping wife Agnis's neck with a razor. Here, the prosecution failed because he did not disfigure her face. ${ }^{83}$ The Act was invoked in the high-profile case of William, Earl of Devonshire, striking Colonel Culpeper in the palace of Whitehall in I687, though with quick resolution that the lack of premeditation and significant injury precluded it. ${ }^{84}$ The 1765 trial of Barny Carrol and William King included an exchange with the attending surgeon about whether Cranley Thomas Kirby's nose was 'slit' (as per the Act), or 'divided', 'incised', 'cut', 'wounded', etc, which was a recurring course of defence (e.g by Coke/ Cooke). They were found guilty, as was Thomas Hand for wounding Joseph Holloway in the arm with a pistol in $1770 .{ }^{85}$ In contrast, Samuel Dale failed to have Thomas Brooks's assault on him upgraded to a felony after he lost the sight in his eye, because unable to prove that Brooks had lain in wait with intent. ${ }^{86}$

The actions required to satisfy 'lying in wait' in Britain were substantially expanded by a ruling from Justice Sir James Eyre in the trial of Thomas Mills in April 1783 , which held it sufficient 'for a man who has a purpose in his mind to do such kind of mischief, and deliberately watches an opportunity to do it'. ${ }^{87}$ It would have little effect, however, as the 1803 revision of the legislation removed the requirement entirely:

\footnotetext{
${ }^{82}$ Ralph Heathcote, The Irenarch: or, Fustice of the Peace's Manual, I77I, 3 rd edn (I78I), I8I-3. His remarks on the case were reprinted in Sylva; or, the Wood (1786), which Jefferson owned.

${ }^{83}$ Trial of William Lee, Old Bailey Proceedings: Accounts of Criminal Trials (hereafter OBP), 6 July i763, LL ref: ti $7630706-45$.

${ }^{84}$ T. B. Howell, A Complete Collection of State Trials (2I vols., I8I6), XI, I353-72.

${ }^{85}$ Trial of Barny Carrol and William King, $O B P$, ıo July i765, LL ref: tr 76507 Io-40; Trial of Thomas Hand, $O B P, 5$ December i77o, LL ref: ti7701205-Iо.

${ }^{86}$ Trial of Thomas Brooks, OBP, i7 December i766, LL ref: tr766i217-63.

${ }^{87}$ In Thomas Leach, Cases in Crown Law, Determined by the Twelve fudges, 3 rd edn (2 vols., I800), I, 297-8.
} 
it remained an unclergyable felony in Lord Ellenborough's Act (43 Geo. III, c. $5^{8}$ [1803]), before being subsumed by the Offences against the Person Act (I86I), which remains in force. Commentators reasoned that by expanding the parameters to 'grievous bodily harm', the statute had more flexibility to incorporate wounds falling short of mayhem, and in places of the body generally covered and thus not 'disfiguring'. ${ }^{88}$

While revisions of Coventry throughout America are beyond the scope of this article, two examples show the diversity of responses. North Carolina still divided the offences according to the principles in the Henrician vs Coventry statutes, and included disfiguring punishment. Their I79I revision stipulated that anyone who would 'of malice aforethought, unlawfully cut out or disable the tongue, or put out an eye of any person with intent to murder, maim or disfigure', and their accomplices, will be pilloried, including loss of both ears, and whipped (first offence), then executed for a second offence. For other actions against the nose, lip, ear or 'any limb or member', performed 'on purpose' and 'with intent to murder, or to maim or disfigure' (thus a more capacious act than that requiring malice and lying in wait), the punishment was only six months' imprisonment and a fine..$^{89}$ New Jersey, in contrast, combined the different actions in 1796 into an offence punishable by fine and/or up to seven years' imprisonment with hard labour. $9^{\circ}$ All jurisdictions took the offence seriously, and many removed or nuanced the criteria for malice and/or lying in wait. The early Virginian revisions had already omitted the waiting requirement, shifting the onus onto the action and its intention. Jefferson noted the lack of restriction to 'wilful and malicious' actions in the older laws, citing further research in Finch, Bracton, Blackstone and others. ${ }^{9^{\mathrm{I}}}$ In the final text sent to the Assembly, the bill omitted the requirement for 'malice forethought', thus further removing the subjective assessment of the accused's mental state from the role of the judiciary and bringing it closer in Jefferson's view to the older laws..$^{2}$

When a revised felony Act was passed on I7 December I792, it did not include a requirement to 'lie in wait', but stipulated that the eligible disfigurements must be inflicted deliberately. It did not preclude benefit of clergy, as the legislature did in the same period for offences like 'buggery, with man or beast', horse stealing and rape. 93 It was not

\footnotetext{
${ }^{88}$ Phil Handler, 'The Law of Felonious Assault in England, I803-6I', Fournal of Legal History, 28 (2007), $183^{-206 .}$

${ }^{89}$ The Acts of the General Assembly of the State of North Carolina (Newbern, I795), ch. VIII.

${ }^{90}$ William Paterson, Lawes of the State of New Fersey (New Brunswick, I80o), 218.

${ }^{91}$ Bill 64 Online.

${ }^{92}$ Jefferson, in Works of Thomas Fefferson, ed. Ford, II, 403.

${ }^{93}$ Samuel Shepherd, The Statutes at Large of Virginia, [1792-1806] ... Being a Continuation of Hening (3 vols., Richmond, I835), I, II2-I3, I78.
} 
until 1796 that the Commonwealth abolished benefit of clergy and restricted the death penalty to first-degree murder, facilitated in part by the construction of a new jail (opening in 180o). ${ }^{94}$ Inefficiencies in prosecution may have encouraged the reduction of capital offences. 95 Some corporal punishments remained: misbehaviour within the jail could prompt extendable solitary confinement on bread and water and/or 'moderate' whipping/s..$^{6}$

The 1796 provision for disfigurement offered two forms for the offence: in the first, it reintroduced the requirement for 'lying in wait' alongside acting 'on purpose and of malice aforethought'; on the other hand, it removed these requirements for any who 'shall voluntarily, maliciously and of purpose, pull or put out an eye while fighting or otherwise', giving theoretically greater protection against the local eye-gouging brawls, rather than the traditionally symbolic nose. If guilty, the offender and his or her 'aiders, abettors and counsellors' would be jailed for two to ten years, and fined up to $\$ \mathrm{I}, 000$, 'three fourths whereof shall be for the use of the party grieved'. ${ }^{97}$ Such compensation rules also removed any need for a separate civil suit by the victim..$^{8}$

This Act was revised again in 1803 . In addition to returning hanging to high treason, it was the first to explicitly exclude slaves as defendants from its provisions. 99 A notable case of I8I held that it could nevertheless protect slaves themselves from malicious disfiguring violence. ${ }^{\text {Io }}$ The revision again rescinded the 'lying in wait' requirement, and created a new two-part offence wherein the key difference was the weapon used: biting, or stabbing or shooting. In each case, the penalty remained the same as in the 1796 Act. ${ }^{\text {Ior }}$ The case of John Somerville, charged with maiming John G. Jackson in I808 (he was ultimately found guilty of misdemeanour assault), still retains reference to 'lying in wait', suggesting it remained an informally aggravating factor even outside of the active statute. ${ }^{102}$ Nevertheless, Henry St George Tucker focused on mayhem as permanent injury that 'disabled' the individual from fighting, and

${ }^{94}$ Ibid., II, $5,8$.

${ }^{95}$ Preyer, 'Crime', 76.

${ }^{96}$ Shepherd, Statutes at Large, II, I3.

${ }^{97}$ Ibid., 7 .

${ }^{98}$ Preyer, 'Crime', 63.

${ }^{99}$ Shepherd, Statutes at Large, II, 405-6.

${ }^{100}$ Commonwealth v Dolly Chapple. The defence argued that as a slave could not own property s/he could not receive the stipulated damages. The prosecution successfully countered that such logic would exclude femes covert from protection, which would be 'monstrous': William Brockenbrough and Hugh Holmes, $A$ Collection of Cases Decided by the General Court of Virginia [I789-18I4] (Philadelphia, I815), I84-6.

${ }^{\mathrm{I}}{ }^{\mathrm{OI}}$ Shepherd, Statutes at Large, II, 405.

${ }^{102}$ Commonwealth v John Somerville, in Brockenbrough and Holmes, Collection of Cases, I64-9. 
the capacity for the court to increase damages if it thought the jury had been too lenient. ${ }^{103}$

While obviously a reduction from the death penalty, Jefferson's suggestion that an assailant should be disfigured 'in like manner' was extraordinary. In the bill he cites Fleta, Britton (which prescribed loss of the equivalent member for men, but loss of the offending hand for women) and the law of King Alfred (Ll. Ælfr. I9. 40), rather than Bracton on membrum pro membro as he referenced in his letter to Wythe. ${ }^{\mathrm{I}}{ }^{\circ} \mathrm{He}$ omits Blackstone, who considered the action arcane and inadequate; however, he may have been influenced by Blackstone's opinion that one of its drawbacks was inability of repetition, in providing for retaliation against a part judged equivalent. ${ }^{105}$ There are precedents for this equivalency in English law. Among the provisions for aggravated cases of affray, for example, anyone convicted for striking another with a weapon (or drawing with intent to do so) in a church or churchyard would be excommunicated, and 'have one of his ears cut off; or, having no ears, be branded with the letter $\mathrm{F}$ in his cheek'. ${ }^{\text {ro6 }}$ It seems unusual for Jefferson to leave such an open field for the judging of this equivalency, given his professed intention to remove wiggle room in courts, but this too carries antecedents in the medieval wergeld that awarded damages for injury based on intricate valuations of body parts.

\section{Disfigurement as a punishment}

The use of disfiguring punishments was by no means unknown in either Europe or America, even if Jefferson was a lone voice for the lex talionis. Branding the hand for benefit of clergy remained a key form of both judicial discretion and physical marking employed by British and American courts, and Arthur Scott demonstrated its frequent use in pre-revolutionary Virginia. ${ }^{107}$ Acts like Coventry had to specifically preclude benefit of clergy for felonies. Until i623 women could not claim benefit of clergy, and thereafter only for petty thefts; in I69I, clergy was extended to them as freely as men. ${ }^{108}$ Many individuals transported to Virginia

\footnotetext{
${ }^{103}$ Henry St George Tucker, Commentaries on the Lawes of Virginia, 1826 (2 vols., Winchester, VA, I837), II, 53-4.

${ }^{104}$ Valerie Allen, 'When Compensation Costs an Arm and a Leg', in Capital and Corporal Punishment in Anglo-Saxon England, ed. Jay Paul Gates and Nicole Marafioti (Woodbridge, 2014), I7-33; William E. Miller, An Eye for an Eye (New York, 2006).

${ }^{105}$ Blackstone, Commentaries, IV, 206.

${ }^{106}$ Ibid., I46.

${ }^{107}$ Arthur Scott, Criminal Law in Colonial Virginia (Chicago, 1930), 319-2I; Jeffrey K. Sawyer, "Benefit of Clergy" in Maryland and Virginia', American Foumal of Legal History, 34 (1990), 49-68.

${ }^{108}$ J. M. Beattie, Policing and Punishment in London 1660-1750: Urban Crime and the Limits of Terror (Oxford, 200I), 277 .
} 
would have carried such marks, such as Sarah Plint, indicted for theft on I6 January I766 and transported for seven years after previously being branded for marrying five husbands. ${ }^{\text {Iog }}$

Branding offenders also served as an ongoing shaming punishment. To do so in the face, or inflict other permanent injury on the only part of the body almost universally uncovered, was acknowledged as a weighted action. While other facial branding had been used in Britain in the seventeenth century, clergy branding 'in the most visible part of the cheek nearest the nose' only appeared from I699 to I7o6, before it returned to the thumb until abolition in $1779 .{ }^{\text {II }}$ The introduction formed part of a general harshening of property laws in the i6gos, but local authorities were hesitant. ${ }^{I I I}$ In repealing the sentence, Parliament noted that rather than acting as a deterrent or corrective, 'such offenders, being rendered thereby unfit to be entrusted in any honest and lawful way, become the more desperate', and in the minds of rehabilitative penal reformers like William Eden the use of stigmatising marks impeded reintegration of a reformed individual into society. ${ }^{112}$ Later American critics of judicial mutilations similarly emphasised that such practices were antithetical to civil societies, and that they fixed the individual as a permanent member of a criminal class unable to start afresh in another colony. ${ }^{\mathrm{II} 3}$ Branding on the cheek for offences like counterfeiting coins did, however, remain on the books. ${ }^{14}$ Other facial marks were also inflicted: in London, I73I, Japhet Crook, alias Sir Peter Stranger, had his ears cut, and nostrils slit by the public hangman under an Elizabethan forgery statue.

Facial marking would continue to be used in British colonies against subordinated bodies: from the branding and judicial disfiguring of enslaved individuals in the West Indies, to the use of forehead tattoos known as godna detailing criminal status in Indian penal law. ${ }^{15}$ Yet, even if corporal punishments such as floggings remained in use in

${ }^{\text {I09 }}$ Trial of Sarah Plint, OBP, ı6 January i766. LL ref: tı766oi 6-7.

${ }^{110}$ 'William III, I698: An Act for the better apprehending prosecuting and punishing of Felons that commit Burglary Housebreaking or Robbery in Shops Ware-houses Coachhouses or Stables or that steal Horses. [Chapter XII. Rot. Parl. Io Gul. III. 3. n. 3.]', in Statutes of the Realm: Volume 7, I695-I7OI, ed. John Raithby (s.1., I820), 5II-I3. British History Online, www.british-history.ac.uk/statutes-realm/vol7/pp5II-5I3 (accessed 29 September 2018).

${ }^{11}$ Beattie, Crime and the Courts in England I66o-I80o (Oxford, I986), 49I; Beattie, Policing, 328-34.

${ }^{112} 5$ Anne c. 6 in William Eden, Principles of Penal Law, 2nd edn (177r), 59.

${ }^{113}$ Ayers, Vengeance and Fustice, 43 .

${ }^{114}$ Blackstone, Commentaries, IV, 99. In his notes on the crime for Bill 64, Jefferson instead cites Æthelstan's and Cnut's sentence of loss of hand, and common law provisions for it as a capital offence.

${ }^{115}$ Elsa Goveia, The West Indian Slave Lawes of the Eighteenth Century (Barbados, I970); Clare Anderson, Legible Bodies: Race, Criminality and Colonialism in South Asia (Oxford, 2004). 
Britain and its colonial regions, forms of legitimate violence designed to ensure lasting stigmatisation were employed by the independent American authorities against their own citizens much later. ${ }^{\mathrm{II} 6}$

Jefferson observed that some of Bill 64's punishments had precedent in the treatment of slaves. From testimonies, runaway advertisements and other sources, we see slaves marked in a wide variety of ways. Ear-cropping is a recurring one, as is the branding of the master's initials or the letter 'R' for 'runaway' on the face and/or body. ${ }^{117}$ A Virginia law of I699 stipulated that a slave convicted of hog-stealing once would be whipped, and twice would have both ears torn at the pillory. ${ }^{\mathrm{I} 8}$ The sentence was extended to any free person in $1748{ }^{119}$ The threat was also thought a good equivalent to swearing on the Bible in capital trials of slaves: 'Negros, Mulattos, or Indians, not being christians' required to testify were to be informed that if they gave false evidence they would lose both ears at the pillory and be whipped. ${ }^{120}$ Formal and informal disfigurements are found throughout British and American slaveholding regions, and were emphasised by anti-slavery writers keen to reveal how 'American taskmasters ... notch the ears of men and women, cut pleasant posies in the shrinking flesh, learn to write with pens of red-hot iron on the human face. ${ }^{\text {'2I }}$ Lewis Clark, an escaped slave from Kentucky testifying to abolitionists in 1842 , also highlighted that disfigurement outside statute was hardly unexpected: 'The law [of Kentucky] don't allow 'em to brand a slave, or cut off his ear; but if they happen to switch it off with a cow hide, nobody says anything about it.' ${ }^{122}$ Early laws based on English vagrancy punishments had marked runaway servants: in I643 a secondoffender's cheek was branded with ' $\mathrm{R}$ ', before this moved to the shoulder in 1658 , and the hair close-cropped for all offenders. ${ }^{123}$ But restrictions

\footnotetext{
${ }^{116}$ On flogging as an increasingly racialised punishment in British colonies, see, e.g., Amanda Nettelbeck, 'Flogging as Judicial Violence: The Colonial Rationale of Corporal Punishment', in Violence, Colonialism and Empire in the Modern World, ed. Phillip Dwyer and Amanda Nettelbeck (Cham, 2018), i I-27; David Killingray, 'The "Rod of Empire": The Debate over Corporal Punishment in the British African Colonial Forces, I888-1946', Fournal of African History, 35 (I994), 20I-I6.

${ }^{117}$ John Hope Franklin and Loren Schweininger, Runaway Slaves: Rebels on the Plantation (New York, 2000), 217-I9; Gwenda Morgan and Peter Rushton, 'Visible Bodies: Power, Subordination and Identity in the Eighteenth-Century Atlantic World', Fournal of Social History, 39 (2005), 39-64, at 47-8; Philip J. Schwarz, Twice Condemned: Slaves and the Criminal Lawes of Virginia, I705-I865 (Union, NJ, I998), 79.

${ }^{118}$ Hening, Statutes at Large, III, I79.

${ }^{119} \mathrm{Ibid}$., VI, I2 I.

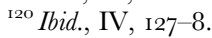

${ }^{121}$ Charles Dickens, American Notes for General Circulation (New York, I842), 86, 89.

${ }^{122}$ National Anti-Slavery Standard, 20-27 October 1842; John W. Blassingame (ed.), Slave Testimony: Two Centuries of Letters, Speeches, Interviews, and Autobiographies (Baton Rouge, 1977), I55.

${ }^{\mathrm{I} 23}$ Hening, Statutes at Large, I, 254-5, 440, 517-18.
} 
grew, while runaway slaves continued to be branded or dismembered (such as losing toes). Into the nineteenth century, slaves faced capital charges for disfiguring white people in cases where white perpetrators would face only fines, pillory or imprisonment. ${ }^{124}$ As Kirsten Fisher notes, the continuation of such practices in the face of increased restraint against white bodies was one way in which racial difference was ingrained. ${ }^{125}$

But despite a significant imbalance in the acceptance, range and frequency of such punishments, corporal punishment including disfigurement was also used on free individuals well into the nineteenth century. Alongside execution, which might be followed by dissection or hanging in chains, public whipping and other forms of judicial mutilation ensured that the body was deeply integrated into 'a public economy of punishment'. ${ }^{126}$ Ear-cropping is the most frequent disfigurement meted out as a punishment in colonial America, including Virginia, and carried British precedents. ${ }^{127}$ In 1624 , the ship captain Robert Cornish (alias Williams) was executed in Virginia for forcibly sodomising one of the ship's boys, William Couse. A number of men linked to the case criticised the execution (on unknown grounds), two of whom were punished by the loss of an ear and either one year of indentured servitude or whipping. ${ }^{128}$ North Carolina included ear-cropping among its penalties for perjury: those guilty were fined, ineligible to give further testimony in any court, and pilloried for an hour before their ears were cut off and nailed to the pillory until sunset. ${ }^{129}$ New England was the most enthusiastic in its use of branding and other marks, but even Pennsylvania - which Virginia would shortly look to after the success of its new penitentiary - only removed remaining branding, ear cropping, etc., in I786. ${ }^{130}$ The army employed branding well into the nineteenth century after it had left other (white) judicial punishments,

\footnotetext{
${ }^{124}$ See, for example, the case of Abram in Alabama I847, who successfully appealed a capital conviction for biting off a section of an overseer's ear because (I) part of the ear was not mayhem, and (2) his life was in danger: in Lawrence Friedman, Crime and Punishment in American History (New York, I993), 92 and 49In. The same offence by others - in language closely modelled on Coventry - would be fined and pilloried: John G. Aikin, A Digest of the Laws of the State of Alabama, 2nd edn (Tuscaloosa, I836), I02.

${ }^{125}$ Kirsten Fischer, Suspect Relations: Sex, Race and Resistance in Colonial North Carolina (Ithaca, 2002), I8o; Anthony S. Parent, Jr, Foul Means: The Formation of a Slave Society in Virginia, I66oI740 (Chapel Hill, 2003), I07, I23-7.

${ }^{126}$ Meranze, Laboratories of Virtue, 187.

${ }^{127}$ Blackstone, Commentaries, IV, I37 (5 Eliz. c. 9: ears nailed to the pillory for perjury), 245 (5. Eliz. c. I4: ears cut and nostrils slit for specific forgery offences).

${ }^{128}$ Murrin, "Things Fearful to Name"', I2; Crompton, 'Homosexuals'.

${ }^{129}$ The Acts of the General Assembly of the State of North Carolina (Newbern, I795), ch. VI.

${ }^{130}$ The Statute at Large of Pennsylvania, Commonwealth of Pennsylvania Legislative Reference Bureau, www.palrb.us/default.php, xii.283; Lawrence Henry Gipson, 'Criminal Codes of Pennsylvania', Journal of Criminal Law and Criminology, 6 (19I5), 323-44.
} 
especially for desertion. William Chester Minor, a Yale-trained surgeon in the Union army, wrote a traumatised account of being tasked with branding an Irish deserter in I864. ${ }^{\text {I3 }}$ Marking the bodies of criminals was one way in which criminal identity could, in theory, be fixed, but this was never certain: cases of innocent disfigurement resembling the legal practices were recorded in Kentucky courts, so that the individual could be defended against misreadings. ${ }^{132}$

In a rare gap, Jefferson offers no citations for cutting women's noses. His letter to Pendleton shows an early intention to use castration to punish 'rape, buggery, \&c.' but makes no mention of nose-cutting, or the use of retaliation for disfigurement. ${ }^{133}$ There is a long global tradition of inflicting nasal wounds upon sexual transgressors, with cases stretching from antiquity to the present, across Egypt, Europe and the Middle East, through Southeast Asia and the Pacific islands. ${ }^{\mathrm{I}} 34$ Punitive rhinotomy was practised by the Blackfeet in the late nineteenth century, although it is not known how widely or for how long this might have existed in America. ${ }^{135}$ It was the status of injuries to the nose as inhonesta vulnera dishonouring wounds - that was in part responsible for the emphatic punishment prescribed by Coventry and related legislation. ${ }^{13}{ }^{6}$ While male and female noses were protected by his disfigurement law, the distinction between castration and nose-boring for the other offences shows his gendering of official judicial actions against this part of the body.

As with the Hebraic 'eye for eye', there was biblical precedent for rhinotomy as a punishment for female sexual transgression (Ezekiel 23:25). Slitting the nose of adulterous or otherwise sexually transgressive women was a widely known threat in early modern Britain. While King Edgar had used nose-cutting for some thefts, it was Cnut (r. Ior6-35) and Archbishop Wulfstan of York $(f$. I002-23) who introduced nasal mutilation - along with loss of the ears - for women convicted of adultery. ${ }^{137}$ Jefferson does not refer to Cnut here, but does elsewhere. His omission

\footnotetext{
${ }^{\mathrm{I}}{ }^{\mathrm{I}}$ Robert Fantina, Desertion and the American Soldier, 1776 -2006 (New York, 2006), 50; Simon Winchester, The Surgeon of Crowthorne: A Tale of Murder, Madness, and the Oxford English Dictionary, I998 (I999), 54-7.

${ }^{132}$ Ayers, Vengeance and fustice, 43 .

${ }^{133}$ Jefferson to Pendleton, 26 August 1776.

${ }^{134}$ Jürgen Wasim Frembgen, 'Honour, Shame, and Bodily Mutilation. Cutting off the Nose among Tribal Societies in Pakistan', foumal of the Royal Asiatic Society of Great Britain E Ireland, I6 (2006), 245-7; Patricia Skinner, 'The Gendered Nose and Its Lack: "Medieval" Nose-Cutting and Its Modern Manifestations', Joumal of Women's History, 26 (2014), 45-67, and Skinner, Living with Disfigurement, esp. ch. 3 .

${ }^{135}$ Adolf Hungry-Wolf, The Blackfoot Papers, vol. 4: Pikunni Biographies (Skookumchuck, 2006), 1085-6.

${ }^{136}$ Emily Cock, Rhinoplasty and the Nose in Early Modern British Medicine and Culture (Manchester University Press, forthcoming 2019).

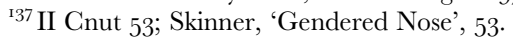


of Cnut 30.4-5, which carried over Edgar's law of talion, is also strange. In the Report of the Revisors, the term was altered from 'cutting' to 'boring'. This may have been intended to suggest restraint, but it also more closely echoes established laws in neighbouring jurisdictions, especially boring the tongue in New England. A final clue appears in Jefferson's legal commonplace book. Here, he closely paraphrases a comment from Henry Home, Lord Kames's history of the criminal law that according to Diodorus Siculus, in ancient Egypt, 'he who committed a rape was castrated. A woman committing adultery, lost her nose, that she might not again allure men to wantonness.' ${ }^{8} 8$ Kames holds this an example of Egypt's 'perfection' of the criminal law, since 'revenge is thereby kept within the strictest bounds, and confined to its proper objects'. ${ }^{39}$ Diodorus may have overstated the neat equivalency in this case, since adultery was more commonly met with death, but castration and rhinotomy were certainly used elsewhere. ${ }^{14^{\circ}}$ While a different crime, the note shows the alignment of rhinotomy with female sexual transgression, their 'allure' to men, and the equivalency with male castration, which evidently had some appeal to Jefferson.

\section{Conclusion}

In Notes on the State of Virginia, Jefferson presented his revised criminal code in an elegant table, arranged according to punishment: Life, Limb, and Labour. The provisions under question are set out as follows: ${ }^{14 \mathrm{I}}$

II. Crimes whose punishment goes to Limb.

$\left.\begin{array}{l}\left.\begin{array}{l}\text { I. Rape, } \\ \text { 2. Sodomy, }\end{array}\right\} \text { Dismemberment. } \\ \text { 4. Maiming, Disfiguring }\end{array}\right\} \begin{aligned} & \text { Retaliation, and the forfeiture of half the lands } \\ & \text { and goods to the sufferer. }\end{aligned}$

\footnotetext{
${ }^{138}$ Jefferson, Legal Commonplace Book, 235; Henry Home, Lord Kames, Historical LawTracts, 2nd edn (Edinburgh, I76r), 49 .

${ }^{139}$ Kames, Historical Law-Tracts, 48.

${ }^{140}$ C. J. Eyre, 'Crime and Adultery in Ancient Egypt', Fournal of Egyptian Archaeology, 70 (1984), 92-105, at 96-7.

${ }^{141}$ Jefferson, in Works of Thomas Jefferson, ed. Ford, IV, 59 .
} 
There is an element of obfuscation in placing castration behind the broader category of 'dismemberment'. Moreover, these laws had not passed when Jefferson published the book. The summary echoes Jefferson's two ostentatiously careful manuscripts of Bill 64, the notes arranged in columns to mirror legal heroes like Coke. ${ }^{12}{ }^{2}$ These carefully elucidate the precedents upon which Jefferson was relying to put forward a code he desired to be marked by 'accuracy, brevity and simplicity'. ${ }^{43}$ Where Dumas Malone had seen the extensive notes as evidence of Jefferson's interest in the topic, Julian Boyd saw the annotations as Jefferson's 'pedantic ostentation', and Dubber an excuse to 'practice his penmanship'. '14

Considering the annotations and research alongside the problematic history of the Coventry Act in practice, however, illuminates why the keen lawyer struggled to find an adequate means of revising the provisions against disfigurement - one that even he grew to dislike. When Beccaria's appeal against capital punishment gained traction among reformers, those still in favour of the punishment were compelled to defend it with unprecedented vigour: Vic Gatrell notes that 'elaborate pleading' was newly necessary, 'because older certainties had become uneasy'. ${ }^{145}$ Jefferson's exhausting annotations of the corporal punishments hint at similar strain to justify punishments that might seem 'revolting'. Virginia's simplifying of the Coventry Act's requirements of intention and circumstance, for all they fluctuated in different revisions, represented attempts to combat the real problems that the Act had faced in practice in Britain, and criticisms of its application. Replacing the death penalty for this and the other offences with proportional punishments was supposed to increase efficacy, justice and rationality in postrevolutionary Virginian law. I am inclined to agree with Peterson that Jefferson was in a sense 'trapped by a misplaced desire for simplicity', in striving for a code so straightforward, proportional and logical that mercy could never be at 'the eccentric impulses of whimsical capricious designing men'. ${ }^{146}$ Neither an out-of-the blue aberration, nor an overlooked hangover from earlier law, Jefferson's lex talionis approach to facial disfigurement as both a crime and a punishment drew on precedents from medieval England and closer to home, and reflected the anxious balance of punishment of body and mind at work in eighteenth-century legal reforms.

\footnotetext{
${ }^{142}$ Julian Boyd, Lyman H. Butterfield and Mina R. Bryan (eds.), The Papers of Thomas Fefferson (Princeton, 1950), II, 310; Dumas Malone, Jefferson and His Time: Fefferson the Virginian (Boston, MA, I948), 269-70.

${ }_{143}$ Jefferson to Wythe, I November 1778.

${ }^{144}$ Malone, Fefferson and His Time, 269; Boyd, Butterfield and Bryan (eds.), Papers of Thomas Fefferson, II, 505; Dubber, "An Extraordinarily Beautiful Document".

${ }^{145}$ Vic Gatrell, The Hanging Tree: Execution and the English People I770-I868 (Oxford, I994), 263.

${ }^{146}$ Peterson, Thomas Fefferson, 127-8; Jefferson to Pendleton, 26 August 1776.
} 